\title{
POLITOLOGY
}

\section{Peculiarities of the formation of gender equality in Ukraine}

\author{
O. Y. Kashaba, I. V. Shcherbina
}

\author{
Ukrainian Engineering and Pedagogical Academy, Kharkiv \\ Corresponding author. E-mail: olga.kashaba@ukr.net, shcheririna63@gmail.com
}

Paper received 14.11.18; Accepted for publication 20.11.18.

\section{https://doi.org/10.31174/SEND-HS2018-185VI31-07}

\begin{abstract}
Gender equality is defined as a process of equitable treatment of women and men; one of the important aspects of the rule of law; indicator of the level of development of an open society; term of prosperity and democracy. Gender parity promotes new, modern ideology of equality and includes the following components: gender equality is considered as an integral part of all policies, programs and projects; achieving gender equality requires the recognition that should be taken into account the specific interests of women and men in the shaping of policies, implementation of programs and projects; gender equality means equal rights and opportunities should be provided regardless of gender; women's access to decision-making at all levels is a central issue in achieving gender equality; for achieving gender equality is important to ensure equal participation of men and women as equal actors in the economic, social and culture-processes; gender equality can be achieved through partnership between women and men on the basis of parity democracy.
\end{abstract}

Keywords: gender, gender stereotypes, gender parity, gender equality.

Over the past decades, the issue of gender equality has become commonplace in public discourse and politics. Governments, business communities, trade unions, and civil society organizations from all over the world are struggling to overcome the discriminatory stereotypes that create barriers on the way of ensuring the equal legal status of men and women, as well as equal opportunities for its realization in public life.

With the efforts of the international community, a number of important policy initiatives have been developed and implemented to ensure a gender perspective through the development of a normative framework, technical assistance, institutional mechanisms. After all, the achievement of gender equality is now becoming a central indicator of the development of each country, and in a globalized world, modern society is forced to address gender stereotypes at once. The UN considers this problem to be global and recommends that states modify existing gender models aimed at preserving the system of unequal values and double standards.

Ukraine belongs to countries where significant changes are taking place in understanding and legitimizing gender relations, and there is a continuous effort to establish an institutional mechanism for ensuring gender equality. Our state has ratified a number of major international instruments on equal rights and opportunities for women and men. At the national level, gender parity is guaranteed, first of all, by the Constitution of Ukraine and a large number of laws. Despite this de facto Ukrainian society remains in this issue not balanced, with manifestations of gender discrimination.

That is why this problem has remained an issue for more than one decade. The uncertainty of gender priorities, postponing the solution of gender inequality to the second plan provoke negative consequences for all spheres of public life

In view of the above, the purpose of the article is to analyze the concept of "gender equality" and determine the factors that influence the process of gender equality formation.

The problems of introducing gender equality have appeared in the countries of Europe with special severity in the twentieth century. From that same time, an active scientific development of this problem begins. So, among sociologists, socio-cultural determinants of gender, the influence of gender on management, gender policy, and stereotypes are studied by D. Best, J. Williams, C. Jeklin, A. Erhard, E. McCoy,
J. Mani, M. Mead, K. Pitman, J. Rozner. S. Salmaniemi, M. Shenli, L. Shrag and others.

In Ukraine, this problem is today one of the most relevant and researched. The domestic humanities analyze the mechanisms of gender policy formation, the legal framework for women\&apos;s participation in political and public life, gender equality and discrimination. Such researchers as M. Bogachevstka-Khomyak, O. Vilkova, N. Hrytsiak, G. Daudov, I. Zherebkina, L. Kobylyanska, T. Kremeshna, T. made a significant contribution to the study and popularization of these issues. Martsenyuk, O. Osaulenko, A. Pashko, L. Smolyar, S. Stanik, O. Yarosh and others.

Gender equality is understood as the level of selfrealization of women and men, the guarantees of observance of rights and freedoms, bearing in mind the features of the sexes, mutual obligations, and joint responsibility in the process of life.

Gender equality implies a society in which women and men have equal opportunities, rights and duties in all spheres of life. Equality between women and men is when people of both sexes can have equal access to education and healthcare, management and government, have equal opportunities to achieve financial independence, working for someone or managing their own business, to fulfill their personal and professional needs of interests. A critical aspect of achieving gender equality is the empowerment of women and more opportunities in various spheres of social development, as well as the involvement of men in the process of achieving gender equality [1].

That is why the American political scientist Ronald Inglehart in his work "Gender Equality and Democracy" noted that "gender equality is a sensitive indicator that shows how developed and democratic the state is" [2, p. 41]. Now we can clearly see that developed societies are gradually moving from a cruel hierarchical management style to a more collegial one. Hierarchical style or conditionally "male" focuses on domination and competition, while the collegial style and, accordingly, "female" puts in the first place in leadership cooperation and support. Therefore, it is considered more effective for maintaining the stability of public institutions.

In general, the affirmation of gender equality is part of a broad cultural transformation that changes the functioning of traditional societies and contributes to the development of 
democratic institutions [3]. Validation of gender equality provides a transition to post-materialistic values of selfrealization, which contribute to the economic development of countries.

For this reason, gender policy in Ukraine, especially in the conditions of the chosen course to build European democratic institutions, appears in the current light. Establishing gender equality faces a number of problems and contradictions of the Ukrainian society. Gender imbalance is largely due to traditions and certain stereotypes that impede the full selfrealization of both genders.

Gender inequality in Ukrainian society is a consequence of both the policy of solving the women\&apos;s issue in the USSR and the specifics of the post-Soviet transit.

Even in Soviet times, women received ample opportunities for work, but in terms of its unequal distribution, their wages are on average lower than those of men. In the Soviet Union, women could receive education on an equal basis with men, as a result of which even now there is a positive imbalance in women\&apos;s higher education. They also had no less, and sometimes greater rights in the sphere of marriage and the family. At the same time, women, as a rule, carried a triple burden of work: not only in the formal but also in the informal economy, for example, subsistence farming, as well as the main caregivers of children and domestic workers.

In the post-Soviet period, there was a certain revival of the patriarchal ideology and practice, which consolidated and deepened the inequality that prevailed during the Soviet era. This is not only a matter of patriarchal stereotypes, which are still supported by many people. The systemic crisis in the conditions of transformation of society was characterized by a certain return to the archaic collectivity and methods of redistributing limited resources based on male dominance. All these trends have formed the basis for discrimination against women in many areas of public life, which are quite difficult to overcome.

Let\&apos;s analyze some examples of gender inequality in Ukraine.

The World Economic Forum periodically reports on the global gender gap by calculating the gender equality index. This option is calculated on the basis of male and female gender statistics in four important areas: economic participation and career opportunities, education, health and survival, political rights and opportunities.

According to the rating of THE GLOBAL GENDER GAP INDEX in 2017, Iceland, Norway, Finland, Rwanda, Sweden, Nicaragua, Slovenia, New Zealand and the Philippines were among the top 10 countries in the gender equality index. Ukraine took 61st place. For comparison, in 2016, our state was on 69 steps, in 2015 - by 67, in 2014-by 56 [2,p.41-42].

Taking into consideration the indicators of past years, it can be argued that the state of gender equality in Ukraine has considerably deteriorated. Thus, in 2006 in the rating THE GLOBAL GENDER GAP INDEX Ukraine took 48th place. It should be noted that this was the best result for the entire period of state independence. Then on some of the four computational parameters, Ukraine approached the mark of 1.00 , which means full gender equality in this sphere $[4, \mathrm{p}$. 42]. So, the best indicators of Ukraine, traditionally have in the field of access of both sexes to education. In particular, it reports on the almost complete coverage of primary and secondary levels of education. With regard to higher education, women even have the best performance (in the ratio of 88 to 77 ).
The indicators of women\&apos;s economic and political participation are significantly worse.

For example, women\&apos;s political leadership is an important indicator of the real progress of society in the direction of the emergence of gender democracy. On average, women in the world only make up $22 \%$ of seats in national parliaments. According to a study on the impact of women on European Union policy "Women in decision-making roles in the European Union", promulgated by OpenPolis in March 2016, the representation of women in parliaments of 17 EU member states is below $30 \%$. In other countries, the best indicator does not exceed $42 \%$ (for example, Sweden, it also establishes gender parity at the level of the Government\&apos;s leadership). Two other countries - France and Slovenia have a gender ratio of 50:50 in government.

This study also shows that most women are headed by ministries related to social policy and work (50\%), family, youth and sports (43\%), education and culture (40\%). Nevertheless, $14 \%$ of European ministers of justice and $7 \%$ of foreign ministers are women. Among the EU institutions, a third of the women\&apos; $\mathrm{s}$ composition has the European Parliament and the European Commission (33\% and 37\% respectively). However, in the Foreign Policy Council, women account for $10 \%$, and women make up $8 \%$ of the Council on Economic and Financial Affairs.

Ukraine is currently ranked 107th in the ranking of only $12 \%$ of women in the Verkhovna Rada. There are no women in the eight committees out of 21 (including budget, preventing and combating corruption, financial policy and banking). As for the government, over the past 10 years, there were no more than three women in any of the Cabinet of Ministers of Ukraine, with two in the modern government.

The situation in the regions leaves much to be desired.

There is a clear trend in Ukraine: the higher the authority, the fewer women there. According to the results of the recent national elections, $46 \%$ of women came from village and village councils. In the region - already $28 \%$.

And though the similar tendency for a certain "alienation" of women from political involvement in general, is still rather characteristic a global trend, indexes nevertheless differ significantly.

Today the trend of discrimination against women continues to exist in the labor market. Despite the fact that according to the statistical level of involvement of women and men in the sphere of employment is approximately the same, there is a major problem in the payment of labor. Men on average earn $10-40 \%$ more than women. Population gender imbalance also testifies: $44 \%$ of respondents admit that it would be better to work under the direction of a person than women. This is primarily a consequence of structural preconditions: horizontal segregation (women are engaged in less prestigious kinds of work) and vertical segregation (women rarely occupy leading positions of a high level). Women are much smaller among more highly paid occupations and businesses. But the greatest concentration of women is observed in the sphere of services, small trade and the budget sphere with their low incomes and a high proportion of hidden unemployment [5, p. 49]. Vertical segregation is a consequence of the fact that men have more career prospects than women. The higher the social status of the post, the fewer women in these posts.

A while back 450 professions for women were banned in Ukraine and, as well as restrictions on their right to work at night (the law was introduced in 1919), women were prohib- 
ited from working as train conductors, night florists, firefighters, divers and fitters; women were forbidden to harvest crops or seeds in farms from trees above 4 meters.

Such rules were established in the list of heavy jobs and jobs with harmful and dangerous working conditions, in which it was forbidden to use women\&apos;s labor. This document was partially canceled in 2017. Finally, it will lose its force after the denunciation by Ukraine of the Convention on the use of women\&apos;s labor in underground work in mines of any kind. This is a significant achievement since, by the repeal of the list in the country, discrimination on the basis of sex was actually enshrined in law.

The issue of respecting and protecting the rights of women in the temporarily occupied territory of Ukraine is relevant and painful. International experts state manifestations of violence, discrimination, gross violation of fundamental rights. Unfortunately, information about these cases is almost not covered in the media, and it is possible that it is deliberately ignored.

So, the modern realities of the Ukrainian society require a new paradigm of state power, which should provide for the optimal use of the human resource, in particular, its female component. Despite the fact that society has made some progress in reducing gender inequalities in economic, political, social and cultural life, various, though less obvious, often veiled forms of discrimination continue to exist. Despite the rapid development of gender legislation and substantial progress in the field of gender equality in Ukraine, significant gender disparities in the area of basic human rights in access to resources and economic opportunities remain. These discrepancies significantly limit women\&apos;s socioeconomic development. Prevalence is also gained by gender gaps in the area of access to resources and opportunities to manage them. Although, as already noted, women have significantly expanded their presence in politics, their representation is still far from parity. Women directly suffer the greatest losses from this inequality, but the costs associated with them permeate the whole society, causing harm to everyone. For this reason, achieving gender equality becomes the central moment of development - its reversible and self- sufficient goal. It contributes to enhancing the country\&apos;s ability to grow, reduce poverty and effective public administration. Therefore, achieving gender equality is an important part of the development strategy, which is designed to enable everyone, both men and women, to improve their living standards. Consequently, the relevance of the problem of gender equality in the modern historical context will certainly remain in the near future. This is due to the fact that the problem of gender inequality and socio-economic and political discrimination of women cannot be solved only by reforms by the state since the system of norms prohibiting any deterioration of women\&apos;s rights is unlikely to work without an effective system of control over the implementation of these standards. To solve the problem, social changes are needed in people\&apos;s minds and in accordance with an objective view of the problem. From this point of view, priority should be given to the issue of the status of women, especially in those problem areas where there are still overt and hidden forms of discrimination, and special measures should be developed, including legislative ones, aimed at achieving real equal opportunities for men and women. , leveling their social status.

Having analyzed all the facts, we can summarize that gender equality contributes to the formation of a new, modern ideology of equality and includes the following components: gender equality is considered an integral part of all policies, programs and projects; achieving gender equality requires recognition that the specific interests of women and men should be taken into account when forming policies, the introduction of programs and projects; achieving gender equality means that equal rights and opportunities must be ensured regardless of gender; women\&apos;s access to decision-making at all levels is central to achieving gender equality; In order to achieve gender equality, it is important to ensure the equal participation of men and women as equal subjects in economic, social and cultural processes; Gender equality can be achieved through a partnership between women and men based on the principles of parity democracy.
1. Кашаба О.Ю., Щербина І.В. Гендерна рівність як складова демократичного розвитку українського суспільства [Текст]/ O. Кашаба, I. Щербина // Humanities and Social Science. - VI (28), I.: 169, june 2018. - C. 7 - 10.

2. Матеріал підготовлений у рамках проекту, який реалізується за фінансової підтримки Європейського фонду демократії (EED) та Уряду Канади [Електронний ресурс]. Режим доступу: http://hvylya.net/analytics/society/gendernapolitika-v-ukrayini-skladniy-shlyah-vid-deklaratsiy-dopozitivnih-diy.html

3. Кашаба О.Ю., Бакуменко О.О., Щербина І.В., Чуєшкова О.В., Сукачова Г.П., Тавшунський О.М., Алєксєєва Г.С. Формування культури гендерної рівності в сучасному українсько-

\section{АТУРА}

му суспільстві як чинника паритетної демократії [Текст] / O. Кашаба, О. Бакуменко, I. Щербина // American Journal of Education. № 4(2) Augast 2018. Volume 124/ 2018/ The Unaversity of Chicago Press, 2018 - p.1078-1095.

4. Количева Ю.О. Гендерна нерівність в Україні та недосконале законодавство як причина іï виникнення [Текст] / Ю. Количева // Актуальні питання сьогодення. - Т.1, 2018. C. $40-46$.

5. Шестаковський О. Гендерна нерівність на ринку праці України: структурі передумови i тривкі стереотипи [Текст]/ О. Шестаковський//Вісник Київського національного університету ім. Тараса Шевченка. - Серія «Соціологія». 1(4), 2013. - C. $49-53$.

\section{REFERENCES}

1. Kashaba O.Iu., Shcherbyna I.V. Henderna rivnist yak skladova demokratychnoho rozvytku ukrainskoho suspilstva [Tekst]/ O. Kashaba, I. Shcherbyna // Humanities and Social Science. - VI (28), I.: 169, june 2018. - S. 7 - 10.

2. Material pidhotovlenyi u ramkakh proektu, yakyi realizuietsia za finansovoi pidtrymky Yevropeiskoho fondu demokratii (EED) ta Uriadu Kanady [Elektronnyi resurs]. Rezhym dostupu: http://hvylya.net/analytics/society/genderna-politika-v-ukrayiniskladniy-shlyah-vid-deklaratsiy-do-pozitivnih-diy.html

3. Kashaba O.Iu., Bakumenko O.O., Shcherbyna I.V., Chuieshkova O.V., Sukachova H.P., Tavshunskyi O.M., Alieksieieva H.S. Formuvannia kultury hendernoi rivnosti $\mathrm{v}$ suchasnomu

ukrainskomu suspilstvi yak chynnyka parytetnoi demokratii [Tekst] / O. Kashaba, O. Bakumenko, I. Shcherbyna // American Journal of Education. № 4(2) Augast 2018. Volume 124/ 2018/ The Unaversity of Chicago Press, 2018 - p.1078-1095.

4. Kolycheva Yu.O. Henderna nerivnist v Ukraini ta nedoskonale zakonodavstvo yak prychyna yii vynyknennia [Tekst] / Yu. Kolycheva //Aktualni pytannia sohodennia.-T.1, 2018.-S.40-46.

5. Shestakovskyi O. Genderna nerivnist na rynku pratsi Ukrainy: strukturi peredumovy i tryvki stereotypy [Tekst] / O. Shestakovskyi // Visnyk Kyivskoho natsionalnoho universytetu im. Tarasa Shevchenka. - Seriia «Sotsiolohiia». 1(4), 2013. S. $49-53$. 